\title{
EFEKTIVITAS PENGELOLAAN DANA DESA DI KECAMATAN GUNUNGPUTRI KABUPATEN BOGOR PROVINSI JAWA BARAT
}

\author{
Oleh \\ Betty Stevera Masihin ${ }^{1}$, \\ Ermaya Suradinata ${ }^{2}$, Halilul Khairi ${ }^{3}$ \\ ${ }^{1)}$ Kementerian Dalam Negeri Direktorat Jenderal Bina Pemerintahan Desa \\ Program Magister Terapan Studi Pemerintahan Daerah Institut Pemerintahan Dalam Negeri \\ mshebeth@gmail.com \\ ${ }^{2,3)}$ Institut Pemerintahan Dalam Negeri
}

\begin{abstract}
THE EFFECTIVENESS OF VILLAGE FUND MANAGEMENT IN GUNUNG PUTRI SUB DISTRICT, BOGOR DISTRICT, WEST JAVA PROVINCE
\end{abstract}

$V_{b}$

llage has seven sources of income, namely: 1. Village original income, which consists of business results, proceeds from assets, self-help, participation, mutual assistance, and other village income; 2. Village Fund, originating from the National Budgets; 3. Share of local taxes and levies; 4. Village Fund Allocation, which is part of the balanced village funds received by the Regency/City; 5. Financial assistance from the Provincial Budgets and Regency/City budgets; 6. Grants and Donations from third parties that are not binding and; 7. Other legal village income (stated in Article 72 of the Village Law)

Village Funds in accordance with the mandate of Law Number 6 of 2014 concerning Villages, the Government allocates Village Funds, through a transfer mechanism to districts/cities. Based on the allocation of these funds, each Regency/City allocates it to each village based on the number of villages by taking into account the population (30\%), the area (20\%), and the poverty rate (50\%). With the allocation of funds from the National Budgets, to be expected that the development in villages will get better and be able to prosper the village community by maximizing the utilization of the allocated funds.

The ojectives of this study is to describe how the Village Fund is managed, find out the obstacles faced by the Gunungputri District government in managing village funds, and analyze the effectiveness of village fund management in relation to the empowerment of village communities in Gunungputri District, Bogor Regency, West Java Province.

The results of this study is that the implementation of the village fund program in Gunungputri District, Bogor Regency is quite effective. The Village Funds can be managed properly according to laws and regulations, that is the Village Fund is used for village development that leads to the empowerment of village communities. All the village communities can feel the benefits.

Keywords: effectiveness, village fund management, community empowerment. 


\begin{abstract}
AbSTRAK
$\mathrm{D}^{\mathrm{s}}$ alam Undang-undang Desa Pasal 72 menyebutkan bahwa desa mempunyai 7 sumber pendapatan,yaitu: 1. Pendapatan asli desa, yang terdiri dari hasil usaha, hasil aset, swadaya, partisipasi, gotong-royong, dan lain-lain pendapatan asli desa; 2. Dana Desa (DD) yang berasal dari Alokasi Pendapatan dan Belanja Negara/APBN; 3. Bagian dari hasil pajak daerah dan retribusi daerah; 4. Alokasi Dana Desa (ADD) yang merupakan bagian dari dana desa perimbangan yang diterima Kabupaten/Kota; 5. Bantuan keuangan dari APBD Provinsi dan APBD Kabupaten/Kota; 6. Hibah dan Sumbangan dari pihak ketiga yang tidak mengikat dan; 7. Lain-lain pendapatan desa yang sah.

Dana Desa sesuai dengan amanat Undang-Undang No. 6 Tahun 2014 tentang Desa, Pemerintah mengalokasikan Dana Desa, melalui mekanisme transfer kepada Kabupaten/kota. Berdasarkan alokasi Dana tersebut, maka tiap Kabupaten/Kota mengalokasikannya kepada setiap desa berdasarkan jumlah desa dengan memperhatikan jumlah penduduk (30\%), luas wilayah (20\%), dan angka kemiskinan (50\%). Dengan adanya dana alokasi dari Anggaran Pendapatan dan Belanja Negara (APBN) tersebut, diharapkan pembangunan di desa semakin baik dan mampu menysejahterakan masyarakat desa dengan pemanfaatan dana alokasi secara maksimal.

Penelitian ini bertujuan untuk mendeskripsikan bagaimana pengelolaan Dana Desa, mendeskripsikan kendala yang dihadapi pemerintah Kecamatan Gunungputri dalam pengelolaan dana desa.dan untuk menganalisis efektivitas pengelolaan dana desa dalam kaitannya dengan pemberdayaan masyarakat desa di Kecamatan Gunungputri kabupaten Bogor, Provinsi Jawa Barat.

Hasil penelitian ini menunjukkan bahwa pelaksanaan program dana desa di Kecamatan Gunungputri Kabupaten Bogor dapat dikategorikan cukup efektif, di mana Dana Desa yang bersumber dari pemerintah dapat dikelola dengan baik, di mana dalam pengelolaan Dana Desa digunakan untuk pelaksanaan pembangunan desa sesuai dengan program Dana Desa yang disusun sesuai dengan mekanisme perundang-undangan yang berlaku, yakni Dana Desa yang digunakan untuk pembangunan desa yang mengarah kepada pemberdayaan masyarakat desa sehingga manfaat dari pengelolaan Dana Desa dapat dinikmati dan dirasakan oleh seluruh masyarakat desa.
\end{abstract}

Kata kunci: efektivitas, pengelolaan dana desa, pemberdayaan masyarakat

\section{PENDAHULUAN}

Sesuai dengan amanat Undang-Undang No. 6 Tahun 2014 tentang Desa, Pemerintah mengalokasikan Dana Desa, melalui mekanisme transfer kepada Kabupaten/kota. Berdasarkan alokasi Dana tersebut, maka tiap Kabupaten/ Kota mengalokasikannya kepada setiap desa berdasarkan jumlah desa dengan memperhatikan jumlah penduduk (30\%), luas wilayah (20\%), dan angka kemiskinan (50\%). Hasil perhitungan tersebut disesuaikan juga dengan tingkat kesulitan geografis masing-masing desa. Alokasi anggaran sebagaimana dimaksud di atas, bersumber dari Belanja Pusat dengan mengaktifkan program yang berbasis Desa secara merata dan berkeadilan. Besaran alokasi anggaran yang peruntukannya langsung ke Desa ditentukan 10\% dari dan di luar dana Transfer Daerah (on top) secara bertahap. Dengan adanya dana alokasi dari Anggaran Pendapatan dan Belanja Negara (APBN) tersebut, diharapkan pembangunan di desa semakin baik dan mampu menysejahterakan masyarakat desa dengan pemanfaatan dana 
alokasi secara maksimal. Ketentuan pasal tersebut mengamanatkan kepada Pemerintah Kabupaten untuk mengalokasikan dana perimbangan yang diterima kabupaten kepada desa-desa dengan memperhatikan prinsip keadilan dan menjamin adanya pemerataan.

Undang-undang baru, yaitu UndangUndang No. 8 Tahun 2016 tentang Perubahan Kedua Atas Peraturan Pemerintah No. 60 Tahun 2014 tentang Dana Desa Yang Bersumber Dari Anggaran Pendapatan Belanja Negara, yaitu bahwa dalam rangka pelaksanaan penyaluran, pelaporan, serta pemantauan dan evaluasi Dana Desa yang bersumber dari Anggaran Pendapatan dan Belanja Negara, perlu penyesuaian dan menyempurnakan Peraturan Pemerintah No. 60 Tahun 2014 tentang Dana Desa yang Bersumber dari Anggaran Pendapatan dan Belanja Negara sebagaimana telah diubah dengan Peraturan Pemerintah No. 22 Tahun 2015 tentang perubahan atas Peraturan Pemerintah No. 60 Tahun 2014 tentang Dana Desa yang Bersumber dari Anggaran Pendapatan dan Belanja Negara agar pengelolaan Dana Desa lebih efektif dan efisien.

Pada 2019, Menteri Keuangan menerbitkan Peraturan Menteri Keuangan tentang Pengelolaan Dana Desa, yakni
Peraturan Menteri Keuangan tersebut bernomor 205/PMK.07/2019 tentang Pengelolaan Dana Desa. yang mana dengan diterbitkan Peraturan Menteri ini maka Peraturan Menteri Keuangan No. 193/ PMK.07/2018 dinyatakan tidak berlaku.

Kabupaten Bogor Provinsi Jawa Barat yang berbatasan dengan Ibu kota Negara merupakan kabupaten dengan jumlah penduduk besar terdiri dari 417 Desa yang berada di seluruh wilayah Kabupaten Bogor, kondisi tersebut menjadikan Kabupaten Bogor memperoleh porsi anggaran Dana Desa (DD) yang relatif besar, yakni pada 2017 serbesar Rp371.999.170.000.-tahun 2018 sebesar Rp371.999.170.000,-dan tahun 2019 sebesar Rp488.434.210.000,yang mana Penetapan dan penyaluran Dana Desa ini diatur dengan Peraturan Bupati Bogor.

Untuk lebih jelas Pengalokasian Dana Desa Daerah Kabupaten Bogor, sesuai Perbup Bogor No. 33 Tahun 2017 tentang Dana Desa Tahun Anggaran 2017, Perbup Bogor No. 50 Tahun 2018 tentang Penetapan dan Tata Cara Penyaluran Dana Desa Tahun Anggaran 2018, dan Perbup Bogor No. 21 Tahun 2019 tentang Penetapan dan Tata Cara Penyaluran Dana Desa Tahun Anggaran 2019 dapat dilihat pada tabel 1.

Tabel 1 Penetapan Besaran Dana Desa Kabupaten Bogor Tahun Anggaran 2017 - 2019

\begin{tabular}{cccccc}
\hline No. & Tahun & $\begin{array}{c}\text { Total Dana Desa } \\
\text { Daerah }\end{array}$ & $\begin{array}{c}\text { Dana Desa } \\
\text { berdasarkan } \\
\text { Alokasi Dasar }\end{array}$ & $\begin{array}{c}\text { Dana Desa } \\
\text { Berdasarkan } \\
\text { Alokasi } \\
\text { Afirmasi }\end{array}$ & $\begin{array}{c}\text { Dana Desa } \\
\text { Berdasarkan } \\
\text { Alokasi Formula }\end{array}$ \\
\cline { 3 - 6 } & & $\mathbf{( R p )}$ & $\mathbf{( R p )}$ & $\mathbf{( R p )}$ & (Rp) \\
\hline 2. & 2017 & 371.999 .170 .000 & 299.703 .872 .000 & 0 & 72.295 .298 .000 \\
3. & 2018 & 371.999 .170 .000 & 299.703 .872 .000 & 0 & 72.295 .298 .000 \\
\hline
\end{tabular}

Sumber: Perbup Bogor 2017-2019 
Tabel 2 Pengalokasian Dana Desa Kecamatan Gunungputri Tahun 2019

\begin{tabular}{clccc}
\hline No. & \multicolumn{1}{c}{ Nama Desa } & $\begin{array}{c}\text { Dana Desa } \\
\text { Alokasi Dasar } \\
(\mathrm{Rp})\end{array}$ & $\begin{array}{c}\text { Dana Desa } \\
\text { Alokasi Formula } \\
(\mathrm{Rp})\end{array}$ & $\begin{array}{c}\text { Total Dana Desa } \\
\text { (DD) } \\
\text { (Rp) }\end{array}$ \\
\hline 1. & Wanaherang & 672.421 .387 & 286.228 .279 & 958.650 .066 \\
2. & Bojongkulur & 672.421 .387 & 265.719 .617 & 938.141 .004 \\
3. & Ciangsana & 672.421 .387 & 279.544 .613 & 951.966 .000 \\
4. & Gunungputri & 672.421 .387 & 226.313 .786 & 898.735 .173 \\
5. & Bojongnangka & 672.421 .387 & 265.599 .041 & 938.020 .428 \\
6. & Tlajungudik & 672.421 .387 & 312.582 .020 & 985.003 .407 \\
7. & Cicadas & 672.421 .387 & 335.867 .317 & 1.008 .288 .704 \\
8. & Cikeasudik & 672.421 .387 & 326.580 .363 & 999.001 .750 \\
9. & Nagrak & 672.421 .387 & 222.881 .533 & 895.302 .920 \\
10. & Kranggan & 672.421 .387 & 260.799 .312 & 933.220 .699 \\
\hline
\end{tabular}

Sumber: Perbup Bogor Tentang Penyaluran Dana Desa T.A. 2019

Dari penetapan besaran Dana Desa Kabupaten Bogor akan dialokasikan ke 40 Kecamatan yang ada di Kabupaten Bogor. Salah satu Kecamatan yang mendapat pengalokasian Dana Desa yang menjadi lokasi penelitian dalam penulisan ini adalah Kecamatan Gunungputri. Untuk mengetahui lebih jelasnya tentang perkembangan penerimaan Dana Desa yang diterima oleh desa-desa yang ada di Kecamatan Gunungputri sesuai Perbup Bogor tahun 2019, dapat dilihat pada tabel 2 di atas.

Berdasarkan tabel di atas, terlihat bahwa cukup besar pengalokasian Dana Desa yang diterima masing-masing desa di Kecamatan Gunungputri, Besarnya dana yang harus dikelola oleh pemerintah desa memiliki risiko yang cukup tinggi dalam pengelolaannya, Oleh sebab itu, sebagaimana dalam UndangUndang Desa, pemerintah, pemerintah provinsi, dan Pemerintah Kabupaten/ kota turut membantu memberdayakan masyarakat desa dengan pendampingan dalam perencanaan, pelaksanaan, dan pemantauan pembangunan desa.

Adapun fokus utama dalam penelitian ini adalah efektivitas Pengelolaan dana desa di Kecamatan Gunungputri, terutama dalam menunjang perekonomian masyarakat Desa sebagai sasaran utama dalam program tersebut. Seperti yang telah dipaparkan di depan bahwa jumlah dana yang dialokasikan dalam program dana desa sangat besar, sehingga membutuhkan penanganan serius agar program-program yang dilaksanakan memiliki efektivitas yang tinggi terhadap tujuan yang ingin dicapai. Maka untuk mengetahui tingkat efektivitas tersebut, dapat dilakukan dengan mengadakan penelitian secara mendalam sehingga didapatkan data akurat mengenai program-program yang telah dijalankan.

Berdasarkan uraian-uraian dalam latar belakang masalah, maka yang menjadi masalah pokok dalam penelitian adalah:

1. Bagaimana pelaksanaan pengelolaan dana desa di Kecamatan Gunungputri Kabupaten Bogor?

2. Bagaimana efektivitas pengelolaan dana desa dapat memberikan manfaat bagi masyarakat desa di Kecamatan Gunungputri? 


\section{KAJIAN PUSTAKA}

\section{Efektivitas}

Secara etimologi, efektivitas berasal dari bahasa inggris effective yang berarti berhasil atau dilakukan dengan baik. Efektif menurut Kamus Besar Bahasa Indonesia berarti ada efeknya (akibatnya, pengaruhnya, kesannya), manjur atau mujarab (tentang obat), dapat membawa hasil, berhasil guna (tentang usaha, tindakan) dan mulai berlaku (tentang undang-undang, peraturan). Sedangkan keefektifan mempunyai arti keadaan berpengaruh, keberhasilan (tentang usaha, tindakan). Adapun secara terminologi, beberapa ahli mendefinisikannya sebagai berikut.

a. Menurut Hidayat (1984: 41), efektivitas adalah suatu ukuran yang menyatakan seberapa jauh target (kuantitas, kualitas dan waktu) telah tercapai, di mana makin besar persentase target yang dicapai, makin tinggi efektivitasnya.

b. Pendapat serupa dikemukakan oleh Sedarmayanti bahwa efektivitas merupakan suatu ukuran yang memberikan gambaran mengenai pencapaian unjuk kerja yang maksimal dan seberapa jauh target (kualitas, kuantitas dan waktu) dapat tercapai.

c. Habey (dalam Mangkunegara, 2003: 16) berpendapat bahwa efektif adalah tepat mengenai sasaran, artinya segala sesuatu yang dilaksanakan sesuai dengan rencana yang telah ditentukan.

d. Sondang P. Siagian berpendapat bahwa efektivitas kerja adalah penyelesaian pekerjaan tepat pada waktu yang telah ditetapkan. Artinya pelaksanaan tugas dinilai baik dan tidaknya sangat bergantung pada bilamana tugas itu diselesaikan.

Dari beberapa definisi yang telah dikemukakan di atas, dapat disimpulkan bahwa efektivitas merupakan ukuran keberhasilan dari sebuah organisasi maupun sebuah program, oleh karena itu efektivitas sangat bergantung pada proses yang dilakukan. Karena proses merupakan jalan yang harus dilalui, maka sebuah proses memiliki peran yang sangat penting dalam rangka mencapai tujuan yang diharapkan.

Adapun kriteria untuk mengukur efektivitas, ada beberapa pendekatan yang bisa dilakukan. Menurut Martani dan Lubis, ada tiga pendekatan yang dapat digunakan untuk mengukur efektivitas organisasi, yakni:

1. Pendekatan sumber (resource approach), yakni mengukur efektivitas dari input. Pendekatan mengutamakan adanya keberhasilan organisasi untuk memperoleh sumber daya, baik fisik maupun nonfisik yang sesuai dengan kebutuhan organisasi.

2. Pendekatan proses (process approach) adalah untuk melihat sejauh mana efektivitas pelaksanaan program dari semua kegiatan proses internal atau mekanisme organisasi.

3. Pendekatan sasaran (goals approach) di mana pusat perhatian pada output, mengukur keberhasilan organisasi untuk mencapai hasil (output) yang sesuai dengan rencana.

\section{Pengelolaan}

Dalam Kamus Besar Bahasa Indonesia disebutkan bahwa pengelolaan adalah proses atau cara perbuatan mengelola atau proses melakukan kegiatan tertentu dengan menggerakkan tenaga orang lain, proses yang membantu merumuskan kebijaksanaan dan tujuan organisasi atau proses yang memberikan pengawasan pada semua hal yang terlibat dalam pelaksanaan kebijaksanaan dan pencapaian tujuan.

Marry Parker Follet mendefinisikan pengelolaan adalah seni atau proses dalam menyelesaikan sesuatu yang terkait dengan pencapaian tujuan. Dalam penyelesaian akan 
sesuatu tersebut, terdapat tiga faktor yang terlibat

1. Adanya penggunaan sumber daya organisasi, baik sumber daya manusia maupun faktor-faktor produksi lainnya.

2. Proses yang bertahap mulai dari perencanaan pengorganisasian pengarahan dan pengimplementasian, hingga pengendalian dan pengawasan.

3. Adanya seni dalam penyelesaian pekerjaan.

Dapat disimpulkan bahwa pengelolaan (manajemen) adalah suatu cara atau proses yang dimulai dari perencanaan, pengorganisasian, pengawasan dan evaluasi untuk mencapai suatu tujuan yang telah ditentukan agar berjalan efektif dan efisien.

\section{Pemberdayaan Masyarakat}

Pemberdayaan masyarakat adalah sebuah konsep pembangunan ekonomi yang merangkum nilai-nilai sosial. Konsep ini mencerminkan paradigma baru pembangunan, yakni yang bersifat "people centred, participatory, empowering, and sustainable" (Chambers, 1995). Konsep ini lebih luas dari hanya semata-mata memenuhi kebutuhan dasar (basic needs) atau menyediakan mekanisme untuk mencegah proses pemiskinan lebih lanjut (safety net), yang pemikirannya belakangan ini banyak dikembangkan sebagai upaya mencari alternatif terhadap konsep-konsep pertumbuhan pada masa yang lalu. Konsep ini berkembang dari upaya banyak ahli dan praktisi untuk mencari apa yang antara lain oleh Friedman (1992) disebut sebagai alternative development, yang menghendaki inclusive democracy, appropriate economic growth, gender equality and intergenerational equaty".(Ginanjar K., 1997: 55)

Pemberdayaan masyarakat yang berintikan kemampuan dan kemandirian masyarakat dalam proses pembangunan dapat dilakukan melalui tahapann pengelolaan pembangunan yaitu tahap perencanaan kegiatan, tahap pengkajian keadaan desa untuk perencanaan, tahap pelaksanaan, tahap monitoring dan tahap evaluasi pembangunan.

Keberhasilan pemberdayaan masyarakat tidak lepas dari partisipasi masyarakat. Seperti diungkapkan Prestby dalam Wrihatnolo dan Dwidjowijoto (2007: 181) bahwa partisipasi penduduk memengaruhi pemberdayaan masyarakat dan organisasi. Partisipasi individu misalnya dalam suatu organisasi sukarela, merupakan kondisi penting karena partisipasi ini memberikan saran efektif yang dapat memberikan keahlian, pengetahuan persepsi diri, persepsi politis, dan praktik bagi individu tersebut untuk meningkatkan pemberdayaan individu yang bersangkutan.

Berdasarkan uraian tersebut di atas, partisipasi sangat dibutuhkan dalam keberhasilan efektivitas pemanfaatan Dana Desa dalam meningkatkan Pemberdayaan Masyarakat di Kecamatan Gunungputri. Hal ini dikarenakan tanpa adanya dukungan dari masyarakat maka pelaksanaan kegiatan Dana Desa tidak dapat berjalan dengan baik. Oleh karena itu, partisipasi masyarakat sangat dibutuhkan dalam pelaksanaan kegiatan pemanfaatan Dana Desa agar tujuan kebijakan dana Desa untuk meningkatkan pemberdayaan masyarakat dapat terwujud.

\section{Metode Analisis ASOCA}

Analisis tata kelola pemerintahan yang baik tidak hanya menggunakan Analisis SWOT (strengths, weakness, opportunities dan threats) melainkan dapat menggunakan analisis ASOCA, yaitu kepanjangan dari ability (kemampuan), Strengths (kekuatan), opportunities (peluang), culture (budaya) dan agility (kecerdasan). Analisis ASOCA menambahkan unsur culture (budaya) dan agility (kecerdasan)sebagai unsur yang penting dalam menemukan strategi pemecahan masalah, pengambilan keputusan, dan dapat dikembangkan dalam mengikuti perubahan, perkembangan zaman dan kebutuhan. 
Tabel 3 Matriks analisis ASOCA yang cocok dengan Negara Indonesia yang majemuk, dan memiliki letak yang strategis di dunia.

\begin{tabular}{|c|c|c|c|}
\hline Faktor Eksternal & $\begin{array}{c}\text { Ability } \\
\text { (Kemampuan) }\end{array}$ & $\begin{array}{l}\text { Strengths } \\
\text { (Kekuatan) }\end{array}$ & $\begin{array}{c}\text { Agility } \\
\text { (Kecerdasan) }\end{array}$ \\
\hline Opportunities (Peluang) & $\begin{array}{l}\text { (A) M e ng g u n a k n } \\
\text { kemampuan untuk } \\
\text { m e ma n f a t k a n } \\
\text { peluang }\end{array}$ & $\begin{array}{l}\text { (C) Menggunakan } \\
\text { kekuatan untuk } \\
\text { memanfaatkan } \\
\text { peluang }\end{array}$ & $\begin{array}{l}\text { (E) Menggunakan } \\
\text { kecerdasan untuk } \\
\text { memanfaatkan } \\
\text { peluang }\end{array}$ \\
\hline Culture (Budaya) & $\begin{array}{c}\text { (B) Melihat Kemampuan } \\
\text { Untuk Menghadapi } \\
\text { Tuntutan Lingkungan } \\
\text { Perubahan Budaya }\end{array}$ & $\begin{array}{l}\text { (D) M e n g g u a k a n } \\
\text { kekuatan untuk } \\
\text { tanggap terhadap } \\
\text { p e } \mathrm{n} g \text { a } \mathrm{r} \text { u h } \\
\text { perubahan budaya }\end{array}$ & $\begin{array}{l}\text { ( F) M e n g u n a k n } \\
\text { k e c e } r d \text { a s a } n \\
\text { untuk menyiasati } \\
p \text { e } n g \text { a } r \text { h } \\
\text { perubahan budaya }\end{array}$ \\
\hline
\end{tabular}

Sinergitas elemen-elemen ASOCA sangat penting yang dapat dikelompokkan ke dalam lingkungan strategis internal dan eksternal yang dapat dibuat dalam bentuk matriks.

Tabel 3 di atas menampilkan matriks sebelas kotak, yang melihat organisasi dari faktor internal organisasi, yaitu ability, Strengths, dan agility serta melihat dari faktor eksternal, yaitu opportunities, dan culture. Enam kotak lainnya merupakan tindakan yang harus dilakukan organisasi ketika faktor internal organisasi diperhadapkan dengan faktor eksternal.

Dalam menggunakan metode analisis ASOCA diperlukan terlebih dahulu mengetahui faktor-faktor yang menjadi bagian dari masing-masing unsur ASOCA. Analisis ini selanjutnya diidentifikasi dari masing-masing faktor lingkungan baik internal maupun eksternal.

\section{METODE PENELITIAN}

Dalam suatu penelitian ilimiah penggunaan metodologi merupakan suatu langkah yang harus ditempuh, agar hasilhasil yang sudah terseleksi dapat terjawab secara valid, reliabel dan objektif, dengan tujuan dapat ditemukan, dibuktikan dan dikembangkan suatu pengetahuan, sehingga dapat digunakan untuk memahami, memecahkan, dan mengantisipasi masalah dalam bidang administrasi publik. Metodologi penelitian yang lasim dipakai dalam penulisan ilimiah adalah metodologi kuantitatif dan metodologi kualitatif. Dalam penelitian ini penulis menggunakan metodologi kualitatif.

Metode yang digunakan untuk mendeskripsikan dan menganalisis efektivitas Pengelolaan Dana Desa di Kecamatan Gunungputri Kabupaten Bogor Provinsi Jawa Barat penulis menggunakan desain penelitian kualitatif dengan pola pendekatan atau teknik penelitian deskriptif.

Melalui metodologi kualitatif, peneliti mendengar dan melihat narasumber berbicara sebenarnya (maka jangan dipengaruhi) tentang dirinya (mereka) sendiri sesuai dengan perspektif masingmasing, dan mengamati mereka berperilaku seadanya terhadap lingkungannya sesuai dengan posisi dan peran di dalam sistem sosial masing-masing pula, kendatipun peneliti menganggapnya aneh. Selanjutnya salah satu ciri penelitian kualitatif adalah bahwa tidak ada hipotesis yang spesifik pada saat penelitian dimulai, hipotesis justru dibangun selama tahap-tahap penelitian, setelah diuji atau dikonfrontasikan dengan 
datayangdiperoleh penelitiselamapenelitian tersebut. Mengingat metode penelitian kualitatif adalah prosedur penelitian yang menghasilkan data deskriptif berupa katakata tertulis atau lisan dari orang-orang dan perilaku yang dapat diamati. Data yang telah dikumpulkan tersebut lalu disusun, dianalisis dan dijelaskan kemudian disimpulkan.

Data atau informasi yang ditetapkan dibedakan mengenai macam dan jenisnya. Mengenai macamnya terdiri dari data primer atau sekunder, sedangkan mengenai jenisnya terdiri dari data kualitatif atau kuantitatif. Data yang diperoleh pada pihak ketiga yang sifatnya cenderung lebih objektif dan telah diolah menjadi data baku dan karena dapat diukur. Biasanya dapat diperoleh dari buku literatur, majalah, jurnal dan hasil penelitian orang lain (kepustakaan dan dokumentasi). Keobjektifan data sekunder dalam penelitian ini lebih bersifat saling mendukung/melengkapi informasi data dari desain kualitatif guna kesahihan data dalam merumuskan maupun menyimpulkan hasil penelitian.

Rumusan konsep dibatasi dengan definisi bahwa implementasi kebijakan Dana Desa dalam perencanaan dan penganggaran pembangunan desa adalah sebagaimana diatur dalam ketentuan Undang-Undang No. 6 Tahun 2014 tentang Desa. Adapun Tujuan utama dibentuknya pemerintahan tidak lain adalah untuk menciptakan kesejahteraan masyarakat untuk dapat menjalani kehidupannya dengan baik.Fungsi utama pemerintahan adalah pelayanan kepada masyarakat maka salah satu upaya peningkatan pelayanan tersebut, yakni dengan pengembangan fungsi organisasi pemerintahan dalam mencapai tujuan secara efektif.

Berpijak pada konsepsi fokus permasalahan yang diteliti, fokus unit analisis penelitian ini adalah analisis terkait perencanaan dan penganggaran pembangunan desa. Sedangkan unit observasi/pengamatan meliputi aktivitas pada pemerintah desa di Kecamatan Gunungputri Kabupaten Bogor Provinsi Jawa Barat. Melalui pemanfaatan unit analisis dan unit observasi penelitian di atas dalam lingkup fokus penelitian sebagaimana telah diuraikan maka dengan memanfaatkan alat bantu informan penelitian, dihimpun data-data yang berkaitan dengan fokus penelitian dimaksud. Dengan informan serta sumber data observasi, akan membantu penghimpunan data yang berkaitan, melalui persepsi para pelaku dan penanggung jawab dalam perencanaan dan penganggaran pembangunan desa melalui dana desa serta observasi/pengamatan yang ada relevansinya dengan pelaksanaan kebijakan pengelolaan dana desa. Ke semua fenomena tersebut dijaring melalui observasi maupun penguraian pertanyaan wawancara yang membangun penelitian ini.

\section{HASIL PENELITIAN DAN PEMBAHASAN}

Berdasarkan kewenangan yang diberikan kepada pemerintah, maka Pemerintah Kabupaten Bogor mengeluarkan Peraturan Bupati (Perbup) Bogor No. 21 Tahun 2019 tentang Tata Cara Pembagian, Penetapan dan Penyaluran Dana Desa Tahun Anggaran 2019. Dalam Peraturan ini dikatakan bahwa Prioritas penggunaan Dana Desa didasarkan pada prinsip-prinsip sebagai berikut.

a. prinsip keadilan, artinya penggunaan Dana Desa mengutamakan hak dan kepentingan seluruh warga Desa tanpa membeda-bedakan;

b. prinsip kebutuhan prioritas, artinya penggunaan Dana Desa mendahulukan kepentingan Desa yang lebih mendesak, lebih dibutuhkan dan berhubungan langsung dengan kepentingan sebagian besar masyarakat Desa;

c. prinsip terfokus, artinya penggunaan Dana Desa mengutamakan pilihan penggunaan Dana Desa pada tiga sampai 
dengan lima jenis kegiatan sesuai dengan kebutuhan sesuai prioritas nasional, provinsi, kabupaten dan desa, dan tidak dilakukan praktik penggunaan Dana Desa yang dibagi rata;

d. prinsip kewenangan Desa, artinya penggunaan Dana Desa mengutamakan kewenangan hak asal usul dan kewenangan lokal berskala Desa;

e. prinsip partisipatif, artinya penggunaan Dana Desa mengutamakan prakarsa, kreativitas dan peran serta masyarakat Desa;

f. prinsip swakelola, artinya penggunaan Dana Desa mengutamakan kemandirian Desa dalam pelaksanaan kegiatan pembangunan Desa yang dibiayai Dana Desa;

g. prinsip berdikari, artinya penggunaan Dana Desa mengutamakan pemanfaatan Dana Desa dengan mendayagunakan sumber daya Desa untuk membiayai kegiatan pembangunan yang dikelola dari, oleh dan untuk masyarakat Desa sehingga Dana Desa berputar secara berkelanjutan di wilayah Desa dan/atau kabupaten;

h. prinsip berbasis sumber daya desa, artinya penggunaan Dana Desa mengutamakan pendayagunaan sumber daya manusia dan sumber daya alam yang ada di Desa dalam pelaksanaan pembangunan yang dibiayai Dana Desa; dan

i. prinsip tipologi desa, artinya penggunaan Dana Desa mempertimbangkan keadaan dan kenyataan karakteristik geografis, sosiologis, antropologis, ekonomi, dan ekologi Desa yang khas, serta perubahan atau perkembangan dan kemajuan Desa. Selanjutnya yang menjadi Prioritas Penggunaan Dana Desa adalah:

(1) Penggunaan Dana Desa diprioritaskan untuk membiayai pelaksanaan program dan kegiatan di bidang pembangunan Desa dan pemberdayaan masyarakat Desa.

(2) Prioritas penggunaan Dana Desa digunakan untuk membiayai pelaksanaan program dan kegiatan prioritas yang bersifat lintas bidang.

Tabel 4 Pengalokasian Dana Desa Kecamatan Gunungputri Tahun 2019

\begin{tabular}{llccc}
\hline & & Total Dana Desa & Bidang & Bidang \\
No. & Nama Desa & (DD) & Pembangunan & $\begin{array}{c}\text { Pemberdayaan } \\
\text { Masyarakat }\end{array}$ \\
\cline { 3 - 5 } & & (Rp) & (Rp) & (Rp) \\
\hline 1. & Wanaherang & 958.650 .066 & 690.228 .048 & 268.422 .018 \\
2. & Bojongkulur & 938.141 .004 & 666.080 .113 & 272.060 .891 \\
3. & Tlajungudik & 985.003 .407 & 709.202 .453 & 275.800 .954 \\
4. & Ciangsana & 951.966 .000 & 663.376 .200 & 285.589 .800 \\
5. & Gunungputri & 898.735 .173 & 647.089 .325 & 251.645 .848 \\
6. & Bojongnangka & 938.020 .428 & 656.614 .300 & 281.406 .128 \\
7. & Cicadas & 1.008 .288 .704 & 685.636 .319 & 322.652 .385 \\
8. & Cikeasudik & 999.001 .750 & 699.301 .225 & 299.700 .525 \\
9. & Nagrak & 895.302 .920 & 617.759 .015 & 277.543 .905 \\
10. & Kranggan & 933.220 .699 & 662.586 .696 & 270.634 .003 \\
\hline
\end{tabular}

Sumber: Kecamatan Gunungputri 
(3) Prioritas penggunaan Dana Desa dapat memberikan manfaat sebesarbesarnya bagi masyarakat Desa berupa peningkatan kualitas hidup, peningkatan kesejahteraan dan penanggulangan kemiskinan serta peningkatan pelayanan publik di tingkat Desa.

Untuk mengetahui lebih jelasnya tentang penerimaan dan Penggunaan Dana Desa di Kecamatan Gunungputri tahun 2019, dapat dilihat pada tabel 4 di atas.

\section{Pengelolaan Penggunaan Dana Desa (DD) Desa Wanaherang}

Terkait dengan pengalokasian Dana Desa dari Kabupaten Bogor tahun 2019 pemerintah Desa Wanaherang menerima sebesar Rp958.650.066,Anggaran Dana Desa ini penyalurannya dalam tiga tahapann. Penyaluran tahap pertama sebesar Rp191.730.013 atau sebesar 20\%, penyaluran tahap kedua sebesar Rp383.460.027 atau sebesar 40\% dan penyaluran tahap ke tiga sebesar
Rp383.460.027,-yang penggunaannya dapat dilihat pada tabel 5:

Adapun paparan data dari Desa Wanaherang terkait dengan pengelolaan Dana Desa di Desa Wanaherang adalah sebagai berikut.

“Dana Desa tahun 2019, hanya diprioritaskan pada pelaksanaan program dan kegiatan di bidang pembangunan desa. Sedangkan pelaksanaan program dan kegiatan di bidang pemberdayaan masyarakat tidak ada satu pun kegiatan. Hal ini jika dihubungkan dengan prioritas penggunaan Dana Desa sesuai aturan yangberlaku, yakni prioritas penggunaan Dana Desa tahun 2019 sesuai dengan Permendes PDTT RI No. 16 Tahun 2018, tentang prioritas penggunaan Dana Desa tahun 2019 Pasal, dapat dikatakan bahwa Prioritas Penggunaan Dana Desa yang dilakukan oleh pemerintah Desa Wanaherang Kecamatan Gunungputri tidak sejalan dengan aturan dimaksud."

Tabel 5 Daftar Realisasi Bidang Pembangunan Desa Wanaherang

\begin{tabular}{|c|c|c|c|c|}
\hline No. & Program Kegiatan & Sasaran/Manfaat & Biaya (Rp) & $\begin{array}{c}\text { Sumber } \\
\text { Dana }\end{array}$ \\
\hline 1. & $\begin{array}{l}\text { Pemagaran Lapangan } \\
\text { Sepak Bola milik Desa }\end{array}$ & $\begin{array}{l}\text { Pemeliharaan Aset milik Pemerintah dan } \\
\text { juga mengembangkan dan pembinaan } \\
\text { masyarakat dalam bidang sepak bola }\end{array}$ & 90.993 .800 & DD \\
\hline 2. & $\begin{array}{l}\text { Betonisasi } \\
\text { Parkiran } \\
\text { Sepak Bola }\end{array}$ & $\begin{array}{l}\text { Pemeliharaan Aset milik Pemerintah dan } \\
\text { juga mengembangkan dan pembinaan } \\
\text { masyarakat dalam bidang sepak bola }\end{array}$ & 87.362 .500 & $\mathrm{DD}$ \\
\hline 3. & $\begin{array}{l}\text { Betonisasi jalan Desa Kp. } \\
\text { Parungdengdek RW.011 }\end{array}$ & $\begin{array}{l}\text { Pemeliharaan Jalan desa dan Peningkatan } \\
\text { Pelayanan kepada masyarakat }\end{array}$ & 201.067 .500 & \\
\hline 4. & $\begin{array}{l}\text { Betonisasi Jalan Desa } \\
\text { RT.001/RW.008 }\end{array}$ & $\begin{array}{l}\text { Pemeliharaan Jalan desa dan Peningkatan } \\
\text { Pelayanan kepada masyarakat }\end{array}$ & 156.968 .500 & DD \\
\hline 5. & $\begin{array}{l}\text { Betonisasi Jalan Desa } \\
\text { Kp. Wanaherang RW.009 }\end{array}$ & $\begin{array}{l}\text { Pemeliharaan Jalan desa dan Peningkatan } \\
\text { Pelayanan kepada masyarakat }\end{array}$ & 189.607 .500 & DD \\
\hline 6. & $\begin{array}{l}\text { Betonisasi Jalan Desa Kp. } \\
\text { Cikuda RW.006-RW.007 }\end{array}$ & $\begin{array}{l}\text { Pemeliharaan Jalan desa dan Peningkatan } \\
\text { Pelayanan kepada masyarakat }\end{array}$ & 232.647 .500 & DD \\
\hline
\end{tabular}

Sumber: Desa Wanaherang Kecamatan Gunungputri 
Selanjutnya cara untuk mengetahui pengelolaan Dana Desa adalah dengan cara memonitoring dari Desa baik kepala Desa, sekretaris dan pendamping Desa, dan dari bapak camat setempat juga ikut memonitoring dalam 3 bulan sekali kemudian dari pihak inspektorat juga mengontrol terhadap penggunaan Dana Desa. Dan dari laporan program juga menjadi acuan untuk mengetahui pengelolaan Dana Desa hal ini dilakukan setiap hari oleh tim pengelola kegiatan bersama aparat Desa. Dan jika anggaran berkurang kemudian ada proyek yang harus dilakukan secara cepat untuk Desa Wanaherang menggunakan swadaya masyarakat dan swakelola.

Berdasarkan hasil penelitian di Desa Wanaherang pengelolaan Dana Desa cukup memadai baik dalam pembangunan Desa atau dalam pemberdayaan masyarakat sudah sesuai rencana meski ada beberapa kendala yang harus segera diperbaiki.

Dengan demikian, dapat dikatakan bahwa pengelolaan Dana Desa di Desa Wanaherang jika diteliti dengan seksama, programprogram yang dilaksanakan oleh pemerintah Desa Wanaherang telah merujuk pada tujuan dari program Dana Desa. Misalnya dengan prinsip swakelola maka dapat mengurangi angka pengangguran di desa dan memajukan perekonomian masyarakat.

\section{Analisis Efektivitas Pengelolaan Dana Desa Kaitannya dengan Pemberdayaan Masyarakat Desa}

Pengertian efektivitas secara umum menunjukkan sampai seberapa jauh tercapainya suatu tujuan. Efektivitas disebut juga efektif, jika tujuan atau sasaran yang telah ditentukan sebelumnya telah tercapai. Efektivitas merupakan unsur pokok untuk mencapai tujuan atau sasaran yang telah ditentukan dalam setiap organisasi.

Dari pengertian di atas, dapat dipahami bahwa efektivitas adalah program yang dijalankan berhasil dan berdaya guna bagi masyarakat, sesuai dengan kebutuhan masyarakat serta dapat dinikmati oleh semua elemen masyarakat dalam jangka waktu yang lama.

Sedangkan efektivitas pengelolaan Dana Desa adalah sebagian dari salah satu identitas pemerintahan terendah dengan jumlah penduduk yang merupakan kesatuan masyarakat dan bertempat tinggal dalam suatu wilayah yang merupakan kesatuan organisasi pemerintahan terendah di bawah camat, yang berhak menyelenggarakan urusan rumah tangganya sendiri.

Oleh karena itu efektivitas penggunaan Dana Desa dalam pengembangan ekonomi adalah suatu keberhasilan terhadap pemberdayaan masyarakat di pengembangan ekonominya, sehingga masyarakat dapat merasakan keberhasilan program Dana Desa terhadap pengembangan ekonominya. Pengembangan ekonomi atau pemberdayaan masyarakat adalah suatu bentuk untuk menyejahterakan masyarakat lewat pengembangan ekonomi. Karena salah satu keberhasilan suatu desa jika pemberdayaan masyarakat berkembang maka kesejahteraan juga dapat dirasakan oleh masyarakat.

Dalam membahas efektivitas pengelolaan Dana Desa kaitannya dengan pemberdayaan Masyarakat di Kecamatan Gunungputri penulis menggunakan teori yang dikemukakan oleh Lubis dan Martani yaitu pendekatan sumber (resource approach), pendekatan proses (process approach), dan pendekatan sasaran (goal approach).

\section{- Pendekatan Sumber (Resource Approach)}

Pendekatan ini mengutamakan adanya keberhasilan organisasi untuk memperoleh sumber daya, baik fisik maupun nonfisik yang sesuai dengan kebutuhan organisasi. Dari segi nonfisik, pada dasarnya sumber daya tersebut telah disiapkan oleh pemerintah, yaitu berupa dana desa yang telah dialokasikan melalui 
APBN. Untuk mendapatkannya, pemerintah desa diharuskan mengadakan pengajuan berupa APBDes yang berisi tentang rencana pelaksanaan program beserta rincian anggarannya.

Dalam hal ini pemerintah Desa Wanaherang telah mendapatkan sumber daya tersebut melalui APBDes sebesar Rp956.650.066 di mana realisasi untuk bidang pembangunan telah digunakan untuk merealisasikan program-program yang telah direncanakan.

Dari segi fisik, pemerintah Desa Wanaherang, mendapatkannya melalui program yang dilaksanakan secara swakelola sesuai dengan peraturan yang ada dengan memanfaatkan sumber daya yang dimiliki oleh desa Masing-masing desa. Maka berdasarkan hal tersebut bisa diambil simpulan bahwa dari pendekatan sumber (resource approach), pelaksanaan program dana desa di Desa Wanaherang Kecamatan Gunungputri dapat dikatakan efektif.

\section{- Pendekatan Proses (Process Approach)}

Pendekatan ini melihat sejauh mana efektivitas pelaksanaan program dari semua kegiatan proses internal atau mekanisme organisasi. Proses pelaksanaan program Dana Desa di Desa Wanaherang, telah dijelaskan pada pembahasan sebelumnya di mana pemerintah Desa Wanaherang, telah melaksanakan program-program melalui mekanisme yang sesuai dengan undang-undang yang berlaku, mulai dari perencanaan, pelaksanaan, penatausahaan, pelaporan hingga pertanggungjawaban dengan tertib dan transparan. Maka hal ini menunjukkan keefektifan proses pelaksanaan program-program tersebut.

\section{- Pendekatan Sasaran (Goal Approach)}

Pendekatan ini berpusat pada output yang dihasilkan dalam merealisasikan sasaran yang hendak dicapai. Output atau hasil yang dimaksud dalam program dana desa dapat dilihat pada realisasi dari program-program yang telah direncanakan sebelumnya. Berdasarkan data realisasi program dana desa di Desa Wanaherang tahun 2019, pemerintah desa telah melaksanakan total enam program pembangunan sarana dan pra sarana dalam bidang transportasi yakini dengan betonisasi jalan desa dan sarana olah raga milik desa.

Selanjutnya, pendekatan sasaran (goals approach) program dana desa dapat dilihat dari realisasi program dalam mengarahkan kepada tujuan yang hendak dicapai. Dari data realisasi program Dana Desa di Desa Wanaherang 2019, terlihat bahwa setiap program yang dilaksanakan, semua mengarah kepada tujuan dari program Dana Desa.

DenganadanyaprogramDanaDesa,halini sudah memberikan dampak positif terhadap pemberdayaan masyarakat. Dampak positif tersebut terlihat dalam realisasi program Dana Desa di Desa Wanaherang Kecamatan Gunungputri program-program yang telah dilaksanakan dalam bidang pembangunan desa, semua mengarah kepada upaya untuk memberdayakan masyarakat.

Mengacu pada tiga upaya pokok dalam setiap pemberdayaan masyarakat yang dikemukakan oleh Mardikanto dan Soebiato, yang disebut Tri Bina, yaitu Bina Manusia, Bina Usaha, dan Bina Lingkungan, Pemerintah Desa Wanaherang Kecamatan Gunungputri telah melaksanakan programprogram dengan lingkup sebagai berikut.

1. Bina Manusia.

Berkaitan dengan bina manusia,
hasil penelitian menunjukkan
bahwa di Kecamatan Gunungputri
dengan penggunaan Dana Desa
belum memprioritaskan pada Bina
Manusianya, sehingga dapat dikatakan
bahwa pengelolaan dan penggunaan
Dana Desa belum efektif.




\section{Bina Usaha}

Berkaitan dengan bina usaha, hasil penelitian menunjukkan bahwa di Kecamatan Gunungputri dalam melaksanakan program Dana Desa memakai prinsip swakelola maka dapat mengurangi angka pengangguran di desa dan memajukan perekonomian masyarakat. Berkaitan dengan hal ini maka dapat dikatakan pengelolaan dan penggunaan Dana Desa cukup efektif.

3. Bina Lingkungan

Adapun program-program yang berkaitan dengan bina lingkungan, hasil penelitian menunjukkan bahwa di Kecamatan Gunungputri telah melakukannya melalui programprogram pembangunan desa, yaitu sebagai berikut.
a. Kegiatan Pembangunan dan Pemeliharaan Jalan Desa.
b. Kegiatan Pembangunan dan Pemeliharaan Sarana dan Prasarana olah raga

Berkaitan dengan hal di atas, maka dapat dikatakan bahwa dalam pengelolaan dan penggunaan Dana Desa cukup efektif.

\section{SIMPULAN}

Berdasarkan hasil penelitian tentang efektivitas Pengelolaan Dana Desa di Kecamatan Gunungputri, maka penulis dapat menarik simpulan sebagai berikut.

1. Berdasarkan pengukuran efektivitas program dana desa menggunakan 3 (tiga) pendekatan menurut Martani dan Lubis, maka pelaksanaan program dana desa di Kecamatan Gunungputri Kabupaten Bogor dapat dikategorikan cukup efektif, di mana Dana Desa yang bersumber dari pemerintah dapat dikelola dengan baik, di mana dalam pengelolaan Dana Desa digunakan untuk pelaksanaan pembangunan desa sesuai dengan program Dana Desa yang disusun sesuai dengan mekanisme perundang-undangan yang berlaku, yakni Dana Desa yang digunakan untuk pembangunan desa yang mengarah kepada pemberdayaan masyarakat desa sehingga manfaat dari pengelolaan Dana Desa dapat dinikmati dan dirasakan oleh seluruh masyarakat desa.

2. Mengacu pada tiga upaya pokok dalam setiap pemberdayaan masyarakat yang dikemukakan oleh Mardikanto dan Soebiato, yang disebut Tri Bina, yaitu Bina Manusia, Bina Usaha, dan Bina Lingkungan, berdasarkan hasil penelitian pemerintah Kecamatan Gunungputri telah melaksanakan pengelolaan Dana Desa yang efektif berkaitan dengan pembinaan dan pemberdayaan masyarakat, karena dalam pelaksanaan program-program dengan menggunakan Dana Desa sangat menjawab kebutuhan masyarakat dalam kaitannya dengan pembinaan masyarakat, yakni pembinaan manusianya, pembinaan usaha dan pembinaan lingkungannya.

3. Dengan pengelolaan Dana Desa yang efektif telah memberikan dampak yang positif dalam upaya memberdayakan masyarakat di Kecamatan Gunungputri. Dampak-dampak tersebut terlihat dalam realisasi program Dana Desa di Desa Wanaherang, di mana program-program yang telah dilaksanakan dalam bidang pembangunan desa dan pemberdayaan masyarakat desa semuanya mengarah kepada upaya untuk memberdayakan masyarakat.

\section{SARAN}

Berdasarkan hasil penelitian dan simpulan yang telah disajikan, ada beberapa saran yang ditawarkan dalam penelitian ini.

1. Untuk akademisi hasil penelitian ini dapat digunakan sebagai sumbangan kontribusi keilmuan terkait efektivitas 
Pengelolaan Dana Desa dan diharapkan dapat menambah referensi terutama bagi mahasiswa Pascasarjana Institut Pemerintahan Dalam Negeri.

2. Bagi Pemerintah Kecamatan Gunungputri, hasil penelitian ini diharapkan dapat menjadi sumbangan pemikiran, saran dan bahan evaluasi dalam menentukan program-program ke depan untuk kemajuan dan kesejahteraan masyarakat desa di Kecamatan Gunungputri.

3. Bagi peneliti, ke depannya diharapkan dapat memperluas populasi, tidak hanya di Kecamatan Gunungputri, akan tetapi di luar Kecamatan Gunungputri sebagai sampel dalam penelitiannya.

\section{DAFTAR RUJUKAN}

Abimanyu, Anggito. 1995. Pembangunan Ekonomi dan Pemberdayaan Masyarakat. Yogyakarta: BPFE UGM.

Anynomeus.1996. Kamus Besar Bahasa Indonesia. Edisi ke-2. Jakarta: Gramedia Pustaka Utama.

Arifiyanto, et al. 2014. Akuntabilitas Pengelolaan Alokasi Dana Desa di Kabupaten

Hoesada, J. 2014. Komite Standar Akuntansi Pemerintah (KSAP). Jakarta.

Herry, 2012. Pengantar Akuntansi Jakarta: Lembaga Penerbit Fakultas Ekonomi Universitas Indonesia.

Kartasasmita, Ginanjar. 1995. Ekonomi Rakyat: Memadukan Pertumbuhan dan Pemerataan. Jakarta: Cides.

Maryunani. 2002. Alokasi Dana Desa. Brawijaya University Press: PT Danar Wijaya

Moleong, Lexy J. 2000. Metodologi Penelitian Kualitatif. Bandung: PT Remaja Rosdakarya.

Muluk, Khoirul.2006. Desentralisasi dan Pemerintahan Daerah. Malang: Bayumedia Publishing.

Raharjo, A. 2006. Membangun Desa Partisipatif. Yogyakarta: Graha Ilmu.
Sugiyono. 2006. Metode Penelitian Kuantitatif, Kualitatif dan R\&D. Bandung: Alfabeta.

Suharto,Edi. 2005. Membangun Masyarakat Memberdayakan Masyarakat. Bandung: RefikaAdi mata.

Sugiyono (2009). Metode Penelitian Kuantitatif \& Kualitatif. Bandung, Alfabeta.

Suharto, Edi (2005). Membangun Masyarakat Memberdayakan Rakyat. Bandung, Refika Aditama.

Sumaryadi, I Nyoman (2005) Perencanaan Pembangunan Daerah Otonom dan Pemberdayaan Masyarakat. Jakarta, Citra Utama.

Sadeli, Lili M. 2015. Dasar-Dasar Akuntansi. PT Buni Aksara, Jakarta.

Suwarjeni, V Wiratna. 2015. Akuntansi Sektor Publik. Pustaka Baru Press, Yogyakarta.

Thoha Miftah. 1991. Beberapa Aspek Kebijakan Birokrasi. Yogyakarta: Widya Mandala.

Tjokroamidjojo, Bintoro (1995) Pengantar Administrasi Pembangunan. Jakarta, PT Gunung Agung.

Wahjudin, Sumpeno (2011) Perencanaan Desa Terpadu. Banda Aceh, Reinforcement Action and Development.

Widjaja, HAW. (2004) Otonomi Desa Merupakan Otonomi yang Bulat dan Utuh. Jakarta, PT Raja Grafindo Persada.

\section{Peraturan Perundang-Undangan}

Undang-Undang No. 6 Tahun 2014 tentang Desa

Undang-Undang No. 23 Tahun 2014 tentang Pemerintahan Daerah

Peraturan Pemerintah No. 72 Tahun 2005 tentang Desa.

Peraturan Pemerintah No. 43 Tahun 2014 tentang Desa

Peraturan Pemerintah No. 60 Tahun 2014 tentang Dana Desa

Peraturan Menteri Dalam Negeri No. 37 Tahun 2007 Pedoman Pengelolaan Keuangan Desa.

Peraturan Menteri Dalam Negeri No. 7 Tahun 2007 tentang Kader Pemberdayaan Masyarakat. 